\title{
Effects of Bifidobacterium Strains Treated with Gastrointestinal Enzymes on Cytokine Induction in RAW 264.7 Macrophage Cells
}

\author{
Dong-Woon Kim*, Sung-Back Cho, Hyun-Jung Jung, Sung-Dae Lee, Sang-Ho Kim, \\ Kyu-Ho Cho, Seog-Jin Kang, and In-Cheul Kim \\ Swine Science Division, National Institute of Animal Science, RDA, Cheonan, 330-801, Korea
}

\begin{abstract}
The objective of the current study was to compare the abilities of undigested and enzymatically digested bifidobacteria to induce nitric oxide and cytokine release in RAW 264.7 macrophage cells. Nine different Bifidobacterium strains derived from herbivorous animals were digested with pepsin and then pancreatin, and the precipitates and supernatants were acquired via centrifugation. The RAW 264.7 cells were incubated with whole cells, the precipitate, or the supernatant, and the macrophage culture supernatants were analyzed with respect to the induction of nitric oxide and cytokines. Pronounced increases in the production of nitric oxide, interleukin (IL)-1 $\beta$, IL-6, IL-12, and tumor necrosis factor- $\alpha$ (TNF- $\alpha$ ) were observed when cultured with whole cells and the precipitates. It is noteworthy that the precipitates in most of the Bifidobacterium strains evidenced a trend toward superior IL-12 release compared with whole cells. The results showed that both whole cells and digested Bifidobacterium sp. are effective at stimulating RAW 264.7 cells to induce the production of nitric oxide and cytokines. The pepsin-pancreatin system used in the current study may be useful in unraveling the mechanism by which ingested lactic acid bacteria modulate the induction of macrophage mediators at the cellular level.
\end{abstract}

Key words: macrophage, nitric oxide, cytokine, bifidobacteria

\section{Introduction}

Lactic acid bacteria have been shown to be beneficial to the health and nutrition of consumers by maintaining or improving intestinal microbial balance, reducing serum cholesterol, and augmenting immunopotentiation activity (Fuller, 1991; Gilliland, 1990; Sanders, 1993). It has been reported previously that these probiotic bacteria are capable of enhancing a variety of host immunological functions via activation of macrophages and lymphocytes (Hatcher and Lambrecht, 1993; Kirjavainen et al., 1999; Sekine et al., 1994), antibody synthesis (Fukushima et al., 1999; Link-Amster et al., 1994), T- and B-cell proliferation (Kang et al., 1994; Takahashi et al., 1993), and antitumor activity (Rafter, 1995; Sekine et al., 1995). Many prior studies have focused principally on the ability of viable cells, heat-killed cells, peptidoglycan, teichoic acid, and/or cell-free extract to induce several macrophage mediators, including nitric oxide, hydrogen peroxide,

*Corresponding author: Dong-Woon Kim, Swine Science Division, National Institute of Animal Science, Cheonan 330-801 Korea. Tel: 82-41-580-3449, Fax: 82-41-580-3459, E-mail: dwkim9405 @korea.kr and cytokines in macrophages (Amrouche et al., 2006; Ouwehand et al., 1999). It has been reported previously that immune network systems are modulated through the variety of soluble molecules secreted by immune cells (Arai et al., 1990). Activated macrophages are capable of secreting a variety of biologically active substances, such as nitric oxide and interleukin (IL)-1 $\beta$, IL-6, and tumor necrosis factor- $\alpha$ (TNF- $\alpha$ ). These macrophage mediators perform a pivotal function in a variety of immune responses, including host defense against infection and tumor formation.

However, orally administered live probiotic bacteria are subject to adverse circumstances as they pass through the gastrointestinal tract, including the acidic $\mathrm{pH}$ of the stomach, bile acids, and pancreatic juices within the small intestine. This results in poor survival and colonization in the intestinal tract (Clark and Martin, 1994; Marteau et al., 1992). The biological functions associated with whole bacterial cells and their cellular components have been extensively evaluated, but few studies of the immune functions of bifidobacteria digested with pepsin followed by pancreatin have been conducted. The principal objective of the current study was to compare the abilities of herbivorous animal-derived Bifidobacterium strains, both 
undigested and enzymatically digested, to induce nitric oxide and cytokine release in RAW 264.7 murine macrophage cells.

\section{Materials and Methods}

\section{Microorganism and culture conditions}

Nine different Bifidobacterium strains derived from herbivorous animals were obtained from the Korean Collection for Type Cultures (Dajun, Korea): Bifidobacterium boum (KCTC 3227), Bifidobacterium pseudolongum (KCTC 3234), Bifidobacterium cuniculi (KCTC 3276), Bifidobacterium thermophilum (KCTC 3376), Bifidobacterium animalis (KCTC 3417), Bifidobacterium magnum (KCTC 3422), Bifidobacterium merycicum (KCTC 3424), Bifidobacterium ruminantiym (KCTC 3425), and Bifidobacterium adolescentis (KCTC 3459). All strains were grown anaerobically in MRS broth (Merck, Germany) containing $5 \%(\mathrm{wt} / \mathrm{vol})$ lactose at $37^{\circ} \mathrm{C}$ until the late log phase. The cells were then collected via $20 \mathrm{~min}$ of centrifugation at $7,000 \mathrm{~g}$ at $4^{\circ} \mathrm{C}$, washed twice in $0.01 \mathrm{M}$ phosphate buffered saline (PBS; $\mathrm{pH}$ 7.2), and stored at $-20^{\circ} \mathrm{C}$ until used.

\section{Enzymatic digestion of bifidobacteria}

Bacterial cell hydrolysates were prepared via a modified version of the procedure described by Boisen and Fernandez (1995). One gram of whole bacterial cells was suspended in $4 \mathrm{~mL}$ of phosphate buffer $(0.1 \mathrm{M}, \mathrm{pH} 6.0)$, and the $\mathrm{pH}$ was adjusted to 2.0 using $1 \mathrm{M} \mathrm{HCl}$. One milliliter of freshly prepared pepsin solution $(10 \mathrm{mg} / \mathrm{mL}$ in $0.01 \mathrm{M} \mathrm{HCl}$; Merck, Germany) was added to the mixture, followed by $6 \mathrm{~h}$ of gentle shaking at $37^{\circ} \mathrm{C}$. Following pepsin treatment, $2 \mathrm{~mL}$ of phosphate buffer $(0.2 \mathrm{M}, \mathrm{pH}$ 6.8) was added to the mixture, and the $\mathrm{pH}$ was adjusted aseptically to 6.8 using $1 \mathrm{M} \mathrm{NaOH}$. The mixture was then treated further with $1 \mathrm{~mL}$ of freshly prepared pancreatin solution $(50 \mathrm{mg} / \mathrm{mL}$ in $0.2 \mathrm{M}$ phosphate buffer, $\mathrm{pH} 6.8$, Sigma, USA) and shaken for $14 \mathrm{~h}$ at $37^{\circ} \mathrm{C}$ in a water bath. The mixture was heated for $10 \mathrm{~min}$ at $72^{\circ} \mathrm{C}$ in order to inactivate pancreatin. The precipitate (insoluble fraction) and supernatant (soluble fraction) from the mixture were collected via $20 \mathrm{~min}$ of centrifugation at $10,000 \mathrm{~g}$ at $4^{\circ} \mathrm{C}$ and then lyophilized. For introduction into tissue culture, the whole cell, precipitates, and supernatants were resuspended in Dulbecco's modified Eagles medium to the desired concentration on a dry weight basis and then heated for $30 \mathrm{~min}$ at $95^{\circ} \mathrm{C}$.

\section{Cell culture}

The RAW 264.7 mouse macrophage cell line was acquired from the Korean Cell Line Bank (Seoul, Korea). The cells were grown in Dulbecco's modified Eagle's medium (Sigma, USA) supplemented with $10 \%(\mathrm{v} / \mathrm{v})$ fetal bovine serum, streptomycin $(100 \mu \mathrm{g} / \mathrm{mL})$, and penicillin $(100 \mathrm{U} / \mathrm{mL})$ at $37^{\circ} \mathrm{C}$ in a $5 \% \mathrm{CO}_{2}$ humidified incubator. The cells used in all of the experiments conducted herein were cultured in triplicate at a density of $5 \times 10^{5}$ cells per $\mathrm{mL}$ in 24-well tissue culture plates with various concentrations of precipitate or supernatant from hydrolyzed Bifidobacterium strains. Lipopolysaccharide (LPS) (E. coli O55:B5; Sigma, USA) was used as a positive control. After $48 \mathrm{~h}$, the culture supernatants were analyzed for nitric oxide and cytokines.

\section{Nitric oxide determination}

The levels of nitric oxide from the culture supernatants were determined via the Griess reaction (Ding et al., 1988). One hundred (100) microliters of culture supernatant was mixed with $2 \mathrm{~mL}$ of distilled water, $200 \mu \mathrm{l}$ of $1 \%$ sulfanilamide in $\mathrm{HCl}$, and $200 \mu \mathrm{L}$ of $0.12 \% \mathrm{~N}$-(1-naphthyl)-ethylenediamine dihydrochloride at room temperature for $10 \mathrm{~min}$; absorbance was measured at $540 \mathrm{~nm}$. The nitrite concentration was then calculated based on a standard curve prepared using sodium nitrite.

\section{Cytokine measurement}

TNF- $\alpha$ and IL- 6 in the cell culture supernatant were quantitated via enzyme-linked immunosorbent assay (Dong et al., 1994). The plates were coated overnight at $4^{\circ} \mathrm{C}$ with $100 \mu \mathrm{L}$ of $1 \mu \mathrm{L} / \mathrm{mL}$ rat anti-mouse TNF- $\alpha$ or IL- 6 antibodies (Endogen, USA). The plates were then washed three times in 0.01 M PBS (pH 7.4) containing $0.2 \%(\mathrm{v} / \mathrm{v})$ Tween 20 (PBST). The plates were incubated for $1 \mathrm{~h}$ at room temperature with $200 \mu \mathrm{L}$ of $0.01 \mathrm{M}$ PBS containing 3\%(w/v) BSA and then washed three times with PBST. Standard cytokines or samples were added at $50-\mu \mathrm{L}$ aliquots per well and incubated for $1 \mathrm{~h}$ at $37^{\circ} \mathrm{C}$. The plates were then washed four times with PBST, incubated for $1 \mathrm{~h}$ with $50 \mu \mathrm{L}$ of $500 \mathrm{ng} / \mathrm{mL}$ of biotinylated rat anti-mouse IL- 6 or TNF- $\alpha$ antibodies, and washed four times in PBST. Then, $50 \mathrm{~mL}$ of streptavidin-horseradish peroxidase conjugate (Pierce, USA) was added to each well, and the plates were incubated for $30 \mathrm{~min}$ and washed five times in PBST. Bound peroxidase conjugate was detected via the addition of $100 \mu \mathrm{L}$ of tetramethylbenzidine and hydrogen peroxide solution (Pierce, USA). The reaction was halted via the addition of $100 \mu \mathrm{L}$ of $1 \mathrm{M}$ 
$\mathrm{H}_{2} \mathrm{SO}_{4}$, and the absorbance at $450 \mathrm{~nm}$ was measured with a Bio-Rad Microplate Reader (Biorad, USA). The cytokine concentration was quantified on the basis of a standard linear dose-response curve. IL-1 $\beta$ and IL-12 concentrations were measured using Opt EIA IL-1 $\beta$ and Opt EIA IL-12p40 (PharMingen, USA) kits, respectively.

\section{Statistical Analysis}

All statistical analyses were conducted using the SAS program (2000; SAS Institute, Cary, NC). Significant differences between treatments were tested by analysis of variance, followed by a comparison between treatments using Duncan's multiple range test. The significance level was set at $p<0.05$.

\section{Results and Discussion}

\section{The morphology of RAW 264.7 cells}

Resident macrophages are capable of synthesizing DNA and proliferating, but activated macrophages lose this ability (Adams and Hamilton, 1987). The morphological changes in RAW 264.7 cells after stimulation with either heat-killed whole cells, or the precipitates or supernatants of digested Bifidobacterium strains, are shown in Fig. 1 and are representative of all the strains. The LPSstimulated cells increased in size, but no such changes were detected in the controls without stimulation (Fig. 1A and 1B). The morphological changes in RAW 264.7 cells incubated with whole cells (Fig. 1C) and with the precipitates (Fig. 1D) were similar to those of LPS, whereas such changes were weak in RAW 264.7 cells incubated with the bacterial supernatant (Fig. 1E). Thus, our find- ings indicated that the whole cells and precipitates, as well as LPS, influence the activation of RAW 264.7 cells.

\section{Nitric oxide production}

RAW 264.7 cells were cultured with whole cells or with the precipitates or supernatants from Bifidobacterium strains treated with pepsin and pancreatin, after which the production of nitric oxide in the culture supernatant was measured via the Griess assay (Table 1).

The production of nitric oxide in the RAW 264.7 cells alone was $3.87 \mu \mathrm{M}$, whereas it was $25.30 \mu \mathrm{M}$ in the cells co-stimulated with LPS $(1 \mu \mathrm{g} / \mathrm{mL})$, which is known to be a strong macrophage activator. When RAW 264.7 cells were co-cultured with $10-100 \mu \mathrm{g} / \mathrm{L}$ of either whole cells or precipitates, nitric oxide production generally increased with increases in the concentration of either whole cells or precipitates. It is worth noting that the level of nitric oxide at $10 \mu \mathrm{g} / \mathrm{L}$ of whole cells or precipitates was similar to that of LPS $(1 \mu \mathrm{g} / \mathrm{mL})$. The level of nitric oxide induction appeared to be lower in the macrophages treated with the bacterial supernatants $(100 \mu \mathrm{g} / \mathrm{mL})$. The level of nitric oxide in the bacterial supernatant was higher in strains 3276, 3422, 3424, and 3425 than in the other strains.

\section{Cytokine production by Bifidobacterium strains}

In an effort to evaluate the effect of digested Bifidobacterium strains on the induction of IL-1 $\beta$, IL-6, IL-12, and TNF- $\alpha$ in the macrophages, RAW 264.7 cells were incubated with either whole cells or the precipitates or supernatants of digested bifidobacteria, and the induction of cytokines in the culture supernatants were subsequently monitored by enzyme-linked immunosorbent assay.
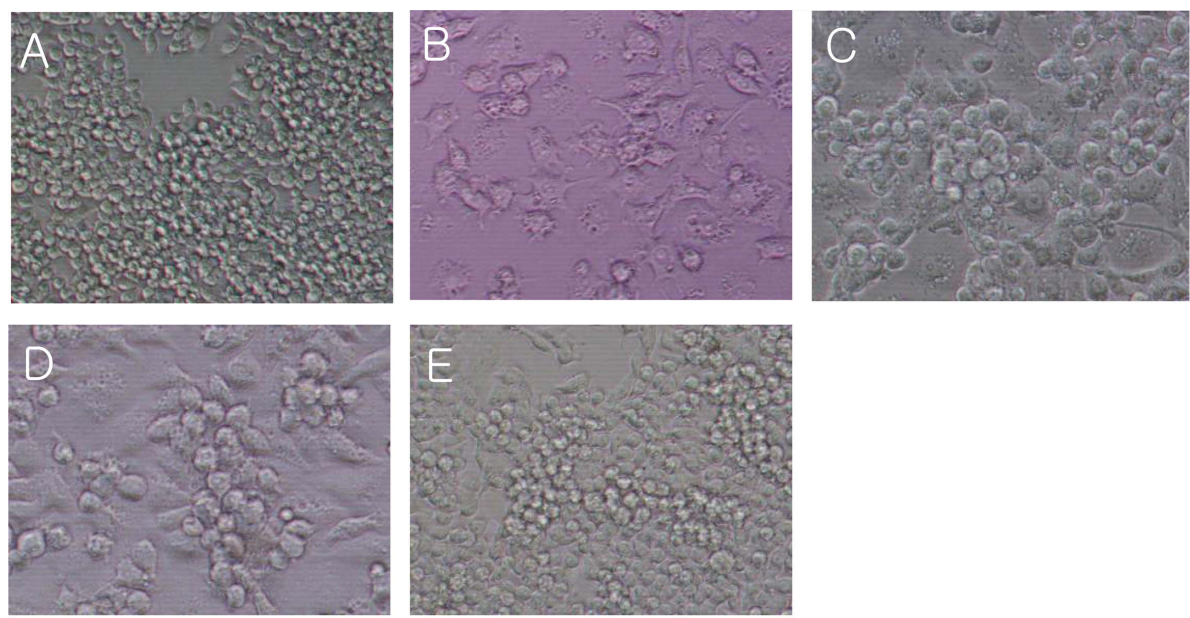

Fig. 1. Morphology of RAW 264.7 cells cultured for $48 \mathrm{~h}$ after the addition of Dulbecco's modified Eagle's medium only (A), $1 \mu \mathrm{g}$ LPS/mL (B), whole cell $(100 \mu \mathrm{g} / \mathrm{mL})$ of Bifidobacterium merycicum 3424 (C), precipitate $(100 \mu \mathrm{g} / \mathrm{mL})$ of Bifidobacterium merycicum 3424 (D), and supernatant (300 $\mu \mathrm{g} / \mathrm{mL})$ of Bifidobacterium merycicum 3424 (E). Magnification A to E: $200 \times$. 
Table 1. Effect of bifidobacteria treated with or without gastrointestinal enzymes on nitric oxide production by RAW 264.7 cells

\begin{tabular}{|c|c|c|c|c|c|c|}
\hline \multirow{2}{*}{ strain } & \multicolumn{2}{|c|}{ Whole cell } & \multicolumn{2}{|c|}{ Precipitate } & \multicolumn{2}{|c|}{ Supernatant } \\
\hline & $10 \mu \mathrm{g} / \mathrm{mL}$ & 100 & 10 & 100 & 100 & 300 \\
\hline B. boum KCTC 3227 & $28.87^{\mathrm{e}}$ & $39.35^{\mathrm{d}}$ & $35.09^{\mathrm{b}}$ & $51.42^{\mathrm{a}}$ & $5.10^{\mathrm{e}}$ & $4.86^{\mathrm{e}}$ \\
\hline B. pseudolongum KCTC 3234 & $32.67^{\mathrm{de}}$ & $54.89^{\mathrm{ab}}$ & $38.06^{\mathrm{b}}$ & $49.10^{\mathrm{a}}$ & $5.72^{\mathrm{de}}$ & $7.29^{\mathrm{de}}$ \\
\hline B. cuniculi KCTC 3276 & $39.93^{\mathrm{bc}}$ & $39.21^{\mathrm{d}}$ & $45.15^{\mathrm{a}}$ & $55.91^{\mathrm{a}}$ & $17.71^{\mathrm{b}}$ & $29.49^{b}$ \\
\hline B. thermophilum KCTC 3376 & $42.42^{\mathrm{b}}$ & $59.40^{\mathrm{a}}$ & $21.14^{\mathrm{d}}$ & $50.40^{\mathrm{a}}$ & $9.01^{\mathrm{cd}}$ & $9.24^{\mathrm{de}}$ \\
\hline B. animalis KCTC 3417 & $33.14^{\text {de }}$ & $58.91^{\mathrm{a}}$ & $40.47^{\mathrm{ab}}$ & $51.40^{\mathrm{a}}$ & $11.85^{\mathrm{c}}$ & $18.93^{\mathrm{c}}$ \\
\hline B. magnum KCTC 3422 & $48.58^{\mathrm{a}}$ & $60.12^{\mathrm{a}}$ & $40.42^{\mathrm{ab}}$ & $52.19^{\mathrm{a}}$ & $32.45^{\mathrm{a}}$ & $33.35^{\mathrm{a}}$ \\
\hline B. merycicum KCTC 3424 & $38.10^{\mathrm{bcd}}$ & $45.19^{\text {cd }}$ & $36.80^{\mathrm{b}}$ & $49.98^{\mathrm{a}}$ & $20.77^{b}$ & $26.80^{\mathrm{b}}$ \\
\hline B. ruminantium KCTC 3425 & $37.98^{\mathrm{bcd}}$ & $50.49^{\text {bc }}$ & $29.33^{\mathrm{c}}$ & $34.78^{\mathrm{b}}$ & $20.82^{\mathrm{b}}$ & $25.50^{\mathrm{b}}$ \\
\hline B. adolescentis KCTC 3459 & $36.26^{\mathrm{cd}}$ & $48.19^{\mathrm{bc}}$ & $27.79^{\mathrm{c}}$ & $53.65^{\mathrm{a}}$ & $9.66^{\mathrm{c}}$ & $11.05^{\mathrm{d}}$ \\
\hline Macrophage (-control) & 3.87 & & & & & \\
\hline LPS $1 \mu \mathrm{g}$ (+control) & 25.30 & & & & & \\
\hline
\end{tabular}

The cells $\left(5 \times 10^{5} /\right.$ well $)$ were stimulated with or without whole cell and bacterial hydrolysates for $48 \mathrm{~h}$ in $5 \% \mathrm{CO}_{2}$ incubator. The amount of nitric oxide production in the culture supernatant was measured via the Griess method. The results are expressed as the mean of $\mu \mathrm{M}$ of nitric oxide from the culture supernatant in triplicate.

a,b,c,d,e: Values with different letters are significantly different within the level $(p<0.05)$.

Table 2. Effect of bifidobacteria treated with or without gastrointestinal enzymes on IL-1 $\beta$ production by RAW 264.7 cells

\begin{tabular}{|c|c|c|c|c|c|c|}
\hline \multirow{2}{*}{ Strain } & \multicolumn{2}{|c|}{ Whole cell } & \multicolumn{2}{|c|}{ Precipitate } & \multicolumn{2}{|c|}{ Supernatant } \\
\hline & $10 \mu \mathrm{g} / \mathrm{mL}$ & 100 & 10 & 100 & 100 & 300 \\
\hline B. boum KCTC 3227 & $654.85^{\mathrm{de}}$ & $1356.33^{\mathrm{c}}$ & $885.96^{\mathrm{c}}$ & $1527.81^{\mathrm{b}}$ & $11.51^{\mathrm{c}}$ & $26.33^{\mathrm{ef}}$ \\
\hline B. pseudolongum KCTC 3234 & $747.81^{\mathrm{d}}$ & $1358.55^{\mathrm{c}}$ & $1235.96^{\mathrm{a}}$ & $1453.37^{\mathrm{bc}}$ & $1.89^{\mathrm{c}}$ & $3.00^{\mathrm{f}}$ \\
\hline B. cuniculi KCTC 3276 & $712.62^{d}$ & $1439.29^{\mathrm{bc}}$ & $1066.33^{\mathrm{b}}$ & $1385.59^{\text {cd }}$ & $7.44^{\mathrm{c}}$ & $244.11^{\mathrm{b}}$ \\
\hline B. thermophilum KCTC 3376 & $1227.44^{b}$ & $1521.14^{\mathrm{b}}$ & $508.18^{\text {de }}$ & $1436.70^{\mathrm{bc}}$ & $5.77^{\mathrm{c}}$ & $8.56^{\mathrm{ef}}$ \\
\hline B. animalis KCTC 3417 & $735.59^{d}$ & $1051.14^{\mathrm{d}}$ & $1028.18^{\mathrm{bc}}$ & $1184.85^{\mathrm{e}}$ & N.D. & $38.92^{\mathrm{e}}$ \\
\hline B. magnum КСТC 3422 & $1027.81^{\mathrm{c}}$ & $991.51^{\mathrm{d}}$ & $1332.26^{\mathrm{a}}$ & $1663.00^{\mathrm{a}}$ & $177.44^{\mathrm{a}}$ & $711.44^{\mathrm{a}}$ \\
\hline B. merycicum КСТC 3424 & $211.15^{\mathrm{f}}$ & $712.63^{\mathrm{e}}$ & $546.33^{\mathrm{de}}$ & $1305.96^{d}$ & $43.74^{b}$ & $200.03^{c}$ \\
\hline B. ruminantium KCTC 3425 & $1485.59^{\mathrm{a}}$ & $1890.03^{\mathrm{a}}$ & $571.52^{d}$ & $1055.96^{\mathrm{f}}$ & $21.52^{\mathrm{c}}$ & $100.77^{d}$ \\
\hline B. adolescentis KCTC 3459 & $520.03^{\mathrm{e}}$ & $1528.18^{\mathrm{b}}$ & $413.00^{\mathrm{e}}$ & $1518.55^{\mathrm{b}}$ & N.D. & $17.81^{\mathrm{ef}}$ \\
\hline Macrophage (-control) & N.D. & & & & & \\
\hline LPS $1 \mu \mathrm{g}$ (+control) & 585.96 & & & & & \\
\hline
\end{tabular}

*N.D.: Not detectable.

Results are expressed as a mean of $\mathrm{pg} / \mathrm{mL}$ of IL- $1 \beta$ from the cell culture supernatant in triplicate.

a,b,c,d,e,f: Values with different letters are significantly different within the level $(p<0.05)$.

The IL-1 $\beta$ level in the RAW 264.7 cells stimulated with LPS $(1 \mu \mathrm{g} / \mathrm{mL})$ was measured at $585 \mathrm{pg} / \mathrm{mL}$ and, as had been expected, no IL-1 $\beta$ was detected in the negativecontrol RAW 264.7 cells alone (Table 2). IL-1 $\beta$ production in the macrophages treated with whole cells or precipitates was markedly induced in all strains. However, the induction of IL- $1 \beta$ in macrophages stimulated with high concentrations of the supernatant $(300 \mu \mathrm{g} / \mathrm{mL})$ was weakly observed in strains 3276,3422 , and 3424.

Bacterial precipitate at a concentration of $10-100 \mu \mathrm{g} /$ $\mathrm{mL}$ evidenced a level of IL-6 induction activity similar to that seen with the whole cells (Table 3). Highly concentrated bacterial precipitate $(100 \mu \mathrm{g} / \mathrm{mL})$ manifested the highest levels of IL-6 induction activity, and this level of activity was similar to that of macrophage induction with
LPS $(1 \mu \mathrm{g} / \mathrm{mL})$. It was observed that the induction of macrophages was weak or barely detectable in the bacterial supernatant $(100 \mu \mathrm{g} / \mathrm{mL})$ whereas an increased level of activity was observed in strains $3276,3422,3424$, and 3425 at higher supernatant concentrations $(300 \mu \mathrm{g} / \mathrm{mL})$. It is worthy of note that IL-12 production in most of the strains was generally higher in the tested range of precipitate concentrations $(10-100 \mu \mathrm{g} / \mathrm{mL})$ than in the bacterial whole cells (Table 4). TNF- $\alpha$ induction activity appeared to occur at a higher level in the macrophages stimulated with whole cells and precipitates at a concentration of 10$100 \mu \mathrm{g} / \mathrm{mL}$ than in macrophages stimulated with LPS, in which it was barely detectable.

Our results generally agree with those of previous studies, i.e., that the production of nitric oxide and several cytokines 
Table 3. Effect of bifidobacteria treated with or without gastrointestinal enzymes on IL-6 production by RAW 264.7 cells

\begin{tabular}{|c|c|c|c|c|c|c|}
\hline \multirow{2}{*}{ Strain } & \multicolumn{2}{|c|}{ Whole cell } & \multicolumn{2}{|c|}{ Precipitate } & \multicolumn{2}{|c|}{ Supernatant } \\
\hline & $10 \mu \mathrm{g} / \mathrm{mL}$ & 100 & 10 & 100 & 100 & 300 \\
\hline B. boum KCTC 3227 & $33.49^{\mathrm{d}}$ & $95.07^{\mathrm{c}}$ & $61.61^{\mathrm{d}}$ & $94.90^{b}$ & N.D. & N.D. \\
\hline B. pseudolongum KCTC 3234 & $65.30^{\mathrm{c}}$ & $99.23^{\mathrm{b}}$ & $80.93^{\mathrm{bc}}$ & $92.92^{\mathrm{b}}$ & N.D. & N.D. \\
\hline B. cuniculi KCTC 3276 & $32.86^{\mathrm{d}}$ & $98.91^{\mathrm{b}}$ & $93.61^{\mathrm{a}}$ & $99.76^{\mathrm{a}}$ & $12.10^{\mathrm{b}}$ & $75.72^{b}$ \\
\hline B. thermophilum KCTC 3376 & $83.51^{\mathrm{b}}$ & $98.11^{\mathrm{b}}$ & $43.36^{\mathrm{f}}$ & $100.57^{\mathrm{a}}$ & N.D. & N.D. \\
\hline B. animalis KCTC 3417 & $83.68^{\mathrm{b}}$ & $99.04^{\mathrm{b}}$ & $86.44^{\mathrm{b}}$ & $99.55^{\mathrm{a}}$ & N.D. & $1.78^{\mathrm{e}}$ \\
\hline B. magnum КСТC 3422 & $29.55^{\mathrm{d}}$ & $93.55^{\mathrm{c}}$ & $97.90^{\mathrm{a}}$ & $100.65^{\mathrm{a}}$ & $42.81^{\mathrm{a}}$ & $89.96^{\mathrm{a}}$ \\
\hline B. merycicum КСТC 3424 & $27.08^{\mathrm{d}}$ & $84.09^{\mathrm{d}}$ & $77.12^{\mathrm{c}}$ & $100.16^{\mathrm{a}}$ & $8.89^{\mathrm{b}}$ & $65.15^{\mathrm{c}}$ \\
\hline B. ruminantium KCTC 3425 & $69.76^{\mathrm{c}}$ & $102.16^{\mathrm{a}}$ & $56.81^{\mathrm{de}}$ & $92.13^{b}$ & $6.94^{\mathrm{b}}$ & $45.12^{\mathrm{d}}$ \\
\hline B. adolescentis KCTC 3459 & $96.02^{\mathrm{a}}$ & $102.08^{\mathrm{a}}$ & $54.68^{\mathrm{e}}$ & $99.78^{\mathrm{a}}$ & N.D. & N.D. \\
\hline Macrophage (-control) & N.D. & & & & & \\
\hline LPS $1 \mu \mathrm{g}$ (+control) & 95.62 & & & & & \\
\hline
\end{tabular}

*N.D.: Not detectable.

Results are expressed as a mean of ng/mL of IL-6 from the cell culture supernatant in triplicate.

$\mathrm{a}, \mathrm{b}, \mathrm{c}, \mathrm{d}, \mathrm{e}, \mathrm{f}$ : Values with different letters are significantly different within the level $(p<0.05)$.

Table 4. Effect of bifidobacteria treated with or without gastrointestinal enzymes on IL-12 production by RAW 264.7 cells

\begin{tabular}{|c|c|c|c|c|c|c|}
\hline \multirow{2}{*}{ Strain } & \multicolumn{2}{|c|}{ Whole cell } & \multicolumn{2}{|c|}{ Precipitate } & \multicolumn{2}{|c|}{ Supernatant } \\
\hline & $10 \mu \mathrm{g} / \mathrm{mL}$ & 100 & 10 & 100 & 100 & 300 \\
\hline B. boum КCTC 3227 & N.D. & $41.14^{\mathrm{d}}$ & $71.62^{\mathrm{b}}$ & $302.09^{\mathrm{a}}$ & N.D. & N.D. \\
\hline B. pseudolongum KCTC 3234 & $24.00^{\mathrm{b}}$ & $188.28^{b}$ & $92.09^{\mathrm{a}}$ & $272.09^{b}$ & N.D. & N.D. \\
\hline B. cuniculi KCTC 3276 & N.D. & $54.47^{\mathrm{d}}$ & $12.09^{\mathrm{e}}$ & $97.81^{\mathrm{e}}$ & N.D. & N.D. \\
\hline B. thermophilum KCTC 3376 & $42.57^{\mathrm{a}}$ & $256.38^{\mathrm{a}}$ & $31.14^{\text {cd }}$ & $212.57^{\mathrm{c}}$ & N.D. & N.D. \\
\hline B. animalis KCTC 3417 & $17.33^{\mathrm{b}}$ & $142.57^{\mathrm{c}}$ & N.D. & $94.47^{\mathrm{e}}$ & N.D. & N.D. \\
\hline B. magnum КСТC 3422 & $14.00^{\mathrm{b}}$ & $185.42^{\mathrm{b}}$ & $45.43^{\mathrm{c}}$ & $210.66^{\mathrm{c}}$ & $6.86^{\mathrm{b}}$ & $26.85^{\mathrm{c}}$ \\
\hline B. merycicum KCTC 3424 & N.D. & N.D. & N.D. & $35.90^{\mathrm{f}}$ & $6.81^{\mathrm{b}}$ & $25.91^{\mathrm{c}}$ \\
\hline B. ruminantium KCTC 3425 & N.D. & $45.43^{d}$ & N.D. & $158.76^{d}$ & $10.66^{\mathrm{b}}$ & $39.71^{\mathrm{b}}$ \\
\hline B. adolescentis KCTC 3459 & N.D. & $19.43^{\mathrm{e}}$ & $19.24^{\mathrm{de}}$ & $258.76^{b}$ & $17.81^{\mathrm{a}}$ & $48.28^{\mathrm{a}}$ \\
\hline Macrophage (-control) & N.D. & & & & & \\
\hline LPS $1 \mu \mathrm{g}$ (+control) & 88.76 & & & & & \\
\hline
\end{tabular}

*N.D.: Not detectable.

Results are expressed as a mean of $\mathrm{pg} / \mathrm{mL}$ of IL-12 from the cell culture supernatant in triplicate.

a,b,c,d,e,f: Values with different letters are significantly different within level $(p<0.05)$.

can be increased significantly by the exposure of RAW 264.7 cells to heat-killed whole cells (Park et al., 1999; Tejada-Simon and Pestka, 1999). Sakai et al. (1996) reported that increased nitric oxide production was observed in J774.1 murine macrophage cells when co-cultured with digested bacterial cell powder derived from Brevibacterium lactofermentum treated with lysozymes and proteases. In this study, whole bacterial cells and the precipitates generally evidenced a similar degree of inductive activity on nitric oxide, IL-1 $\beta$, IL- 6 , and TNF- $\alpha$ production. Interestingly, the precipitate proved to be a better inducer of IL-12 release than did whole bacterial cells. These findings indicate that cytokine inductive ability in the macrophages could be altered by orally administered bifidobacteria hydrolyzed with gastrointestinal digestive enzymes.

It has been reported that phosphopolysaccharide derived from the cell wall components of gram-positive Lactobacillus strains enhanced lymphocyte mitogenicity and macrophage function (Kitazawa et al., 1999; Uemura et al., 2003). The water-soluble polysaccharide fraction acquired following the sonification of Bifidobacterium adolescentis also evidenced immunopotentiation activity (Hosono et al, 1997). In particular, the results of the present study indicated that the induction of cytokine activity in RAW 264.7 cells after stimulation with supernatants from several bacterial strains may result from the existence of water-soluble immunopotentiators derived from bifidobacteria as a result of treatment with digestive enzymes, including pepsin and pancreatin. The composition of cell walls of various bacteria may be strain-dependent. Most lactic acid bacteria contain teichoic acid, but their peptidoglycan composition differs (Schleifer and Kandler, 1972). Differ- 
Table 5. Effect of bifidobacteria treated with or without gastrointestinal enzymes on TNF- $\alpha$ production by RAW 264.7 cells

\begin{tabular}{|c|c|c|c|c|c|c|}
\hline \multirow{2}{*}{ Strain } & \multicolumn{2}{|c|}{ Whole cell } & \multicolumn{2}{|c|}{ Precipitate } & \multicolumn{2}{|c|}{ Supernatant } \\
\hline & $10 \mu \mathrm{g} / \mathrm{mL}$ & 100 & 10 & 100 & 100 & 300 \\
\hline B. boum KCTC 3227 & $31.76^{\mathrm{c}}$ & $52.23^{\mathrm{a}}$ & $30.42^{\mathrm{c}}$ & $45.23^{\mathrm{bc}}$ & N.D. & $0.38^{\mathrm{e}}$ \\
\hline B. pseudolongum KCTC 3234 & $54.02^{\mathrm{a}}$ & $36.88^{\mathrm{c}}$ & $45.26^{\mathrm{b}}$ & $41.55^{\mathrm{cd}}$ & $0.22^{\mathrm{d}}$ & $0.53^{\mathrm{e}}$ \\
\hline B. cuniculi KCTC 3276 & $25.14^{\mathrm{d}}$ & $46.02^{\mathrm{ab}}$ & $27.67^{\text {cd }}$ & $41.13^{\mathrm{cd}}$ & $2.02^{\mathrm{c}}$ & $11.44^{\mathrm{c}}$ \\
\hline B. thermophilum KCTC 3376 & $57.73^{\mathrm{a}}$ & $17.98^{\mathrm{d}}$ & $41.05^{\mathrm{b}}$ & $22.26^{\mathrm{f}}$ & $0.45^{\mathrm{d}}$ & $1.81^{\mathrm{e}}$ \\
\hline B. animalis KCTC 3417 & $53.56^{\mathrm{a}}$ & $34.65^{\mathrm{c}}$ & $40.44^{b}$ & $35.99^{d}$ & $2.15^{\mathrm{bc}}$ & $14.71^{\mathrm{b}}$ \\
\hline B. magnum КСТC 3422 & $38.83^{\mathrm{b}}$ & $40.22^{\mathrm{bc}}$ & $53.36^{\mathrm{a}}$ & $54.80^{\mathrm{a}}$ & $7.45^{\mathrm{a}}$ & $17.08^{\mathrm{a}}$ \\
\hline B. merycicum КСТC 3424 & $12.54^{\mathrm{e}}$ & $40.02^{\mathrm{bc}}$ & $21.46^{\mathrm{d}}$ & $28.26^{\mathrm{e}}$ & $3.31^{\mathrm{b}}$ & $9.54^{\mathrm{d}}$ \\
\hline B. ruminantium KCTC 3425 & $40.83^{\mathrm{b}}$ & $37.01^{\mathrm{c}}$ & $30.35^{\mathrm{c}}$ & $49.37^{\mathrm{ab}}$ & $1.84^{\mathrm{c}}$ & $2.01^{\mathrm{e}}$ \\
\hline B. adolescentis KCTC 3459 & $12.07^{\mathrm{e}}$ & $46.58^{\mathrm{ab}}$ & $15.14^{\mathrm{e}}$ & $42.16^{\mathrm{c}}$ & $1.08^{\mathrm{cd}}$ & $10.88^{\mathrm{cd}}$ \\
\hline Macrophage (-control) & N.D. & & & & & \\
\hline LPS $1 \mu \mathrm{g}$ (+control) & 0.09 & & & & & \\
\hline
\end{tabular}

*N.D.: Not detectable

Results are expressed as a mean of $\mathrm{ng} / \mathrm{mL}$ of TNF- $\alpha$ from the cell culture supernatant in triplicate. a,b,c,d,e: Values with different letters are significantly different within the level $(p<0.05)$.

ences in the immunopotentiation properties of lactobacilli between strains have been attributed to differences in cell wall structures (Sato et al., 1988). The differences in nitric oxide and cytokine induction observed among the Bifidobacterium strains in our study may be attributable to variability in their surface structures, which are susceptible to digestive enzymes.

It has been shown that IL-12 can induce a dominant Th1 cell-associated cytokine profile (Trinchieri, 1994). More recently, Kimoto et al. (2004) reported that certain Lactococcus strains enhance Th1-type immunity. The enhanced IL-12 release observed in the precipitates indicates that the functional properties of the surface structure of whole bacterial cells can be altered by the gut environment, including physical $(\mathrm{pH})$ and chemical (enzyme) conditions, which can affect cell-mediated immunity. When viable Bifidobacterium lactis was fed to lactating mice, enhanced local production of anti- $\beta$-lactoglobulin IgA was detected in the milk and in the intestines (Fukushima et al., 1999). Moreover, both total and anti- $\beta$-lactoglobulin IgA levels in the tissue extract of the small intestine wall were significantly higher in mice fed on nonviable Bifidobacterium longum (Takahashi et al., 1998). IL-6 is critical to mucosal immunity, based on its differentiative effects on IgA-committed B cells and its production in the gut by macrophages, $\mathrm{T}$ cells, and other cells (Beagley et al., 1989; Vinderola et al., 2006). Thus, our results suggest that the enhanced IL- 6 production observed with the whole cells or precipitates of Bifidobacterium sp. may participate in the stimulation of B cells and thereby result in the induction of IgA production in the gastrointestinal immune system.
The results reported in this study suggest that non-viable bifidobacteria treated with digestive tract enzymes increase the production of nitric oxide and several cytokines and may enhance the intestinal immune functions of the host. It has also been shown that probiotic lactic acid bacteria in feed or food supplements may have immunomodulating properties, even if they are rendered non-viable by the gut environment.

\section{References}

1. Adams, D. O., and Hamilton, T. A. (1987) Molecular transductional mechanisms by which Interferon- $\gamma$ and other signals regulate macrophage development. Immunol. Rev. 97, 5-27.

2. Amrouche, T., Boutin, Y., Prioult, G., and Fliss, I. (2006) Effects of bifidobacterial cytoplasm, cell wall and exopolysaccharide on mouse lymphocyte proliferation and cytokine production. Int. Dairy J. 16, 70-80.

3. Arai, K., Lee, F., Miyajima, A., Miyatake, S., Arai, N., and Yokota, T. (1990) Cytokines: coordinators of immune and inflammatory responses. Ann. Rev. Biochem. 59, 783-836.

4. Beagley, K. W., Eldridge, J. H., Lee, F., Kiyono, H., Everson, M. P., and Koopman, W. J. (1989) Interleukins and Immunoglobulin A synthesis: Human and murine intereukin-6 induce high rate Immunoglobulin A secretion in Immunoglobulin A-committed B cells. J. Exp. Med. 169, 2133-48.

5. Boisen, S. and Fernandez, J. A. (1995) Prediction of the apparent ileal digestibility of protein and amino acids in feedstuffs and feed mixtures for pigs by in vitro analyses. Anim. Feed Sci. Techno. 51, 29-43.

6. Clark, P. A., and Martin, J. H. (1994) Selection of bifidobacteria for use as dietary adjuncts in cultured dairy foods: IIITolerance to simulated bile concentrations of human small intestines. Cult. Dairy Prod. J. 29, 18-21.

7. Ding, A. H., Nathan, C. F., and Stuehr, D. J. (1988) Release 
of reactive nitrogen intermediates and reactive oxygen intermediates from mouse peritoneal macrophages. J. Immunol. 141, 2407-2412.

8. Dong, W., Azcona-Olivera, J. L., Brooks, K. H., Linz, J. E., and Pestka, J. J. (1994) Elevated gene expression and production of interleukins 2, 4, 5, and 6 during exposure to vomitoxin(deoxynivalenol) and cycloheximide in the EL-4 thymoma. Toxicol. Appl. Pharmacol. 127, 282-290.

9. Fukushima, Y., Kawata, Y., Mizumachi, K., Kurisaki, J., and Mitsuoka, T. (1999) Effect of bifidobacteria feeding on fecal flora and production of immunoglobulins in lactating mouse. Int. J. Food Microbiol. 46, 193-197.

10. Fuller, R. (1991) Probiotics in human medicine. Gut 32, 439442.

11. Gilliland, S. E. (1990) Health and nutritional benefits from lactic acid bacteria. Fed. Eur. Microbial. Rev. 87, 175-188.

12. Hatcher, G. E., and Lambrecht, R. S. (1993) Augmentation of macrophage phagocytic activity by cell-free extracts of selected lactic acid-producing bacteria. J. Dairy Sci. 76, 2485-2492.

13. Hosono, A., Lee, J., Ametani, A., Natsume, M., Hirayama, M., Adachi, T., and Kaminogawa, S. (1997) Characterization of a Water-soluble Polysaccharide Fraction with Immunopotentiating Actvity from Bifidobacterium adolescentis M1014. Biosci. Biotech. Biothem. 61, 312-316.

14. Kang, K. Y., Park, S. H., and Choe, T. B. (1994) Immunostimulation effect of cell wall components isolated from $\mathrm{Lac}$ tobacillus plantarum. J. Microbiol. Biotechnol. 4, 195-199.

15. Kimoto, H., Mizumachi, K., Okamoto, T., and Kurisaki, J. (2004) New Lactococcus strain with immunomodulatory activity: enhancement of Th1-type immune response. Microbiol. Immunol. 48, 75-82.

16. Kirjavainen, P. V., El-Nezami, H. S., Salminen, S. J., Ahokas, J. T., and Wright, P. F. (1999) The effect of orally administered viable probiotic and dairy lactobacilli on mouse lymphocyte proliferation. FEMS Immunol. Med. Microbiol. 26, 131-135.

17. Kitazawa, H., Itoh, T., Tomioka, Y., Mizugaki, H., and Yamaguchi, T. (1999) Induction of Interferon- $\gamma$ and Interleukin- $1 \alpha$ production in macrophages stimulated with phosphopolysaccharide produced by Lactococcus lactis ssp. cremoris. Int. J. Food Microbiol. 31, 99-106.

18. Link-Amster, H., Rochat, F., Saudan, K. Y., Mignot, O., and Aeschlimann, J. M. (1994) Modulation of a specific humoral immune response and changes in intestinal flora mediated through fermented milk intake. FEMS Immunol. Med. Microbiol. 10, 55-64.

19. Marteau, P., Pochart, P., Bouhnik, Y., Zidi, S., Goderel, I., and Rambaud, J. C. (1992) Survival of Lactobacillus acidophilus and Bifidobacterium sp. in the small intestine following ingestion in fermented milk. A rational basis for the use of probiotics in man. Gastroenterol Clin. Biol. 16, 25-8.

20. Ouwehand, A. C., Kirjavainen, P. V., Gronlund, M. M., and Salminen, S. J. (1999) Adhesion of probiotic microorganisms to intestinal mucus. Int. Dairy J. 9, 623-630.

21. Park, S. Y., Ji, G. E., Ko, Y. T., Hoo, H. K., Ustunol, Z., and
Pestka, J. J. (1999) Potentiation of hydrogen peroxide, nitric oxide, and cytokine production in RAW 264.7 macrophage cell exposed to human and commercial isolates of Bifidobacterium. Int. J. Food Microbiol. 46, 231-241.

22. Rafter, J. J. (1995) The role of lactic acid bacteria in colon cancer prevention. Scand. J. Gastroenterol. 30, 497-502.

23. Sakai, T., Hamakawa, M., and Shirai, K. (1996) Protective effects of digested bacterial cell powder on diarrhea in suckling piglets. Agri-Practice. 17, 23-27.

24. Sanders, M.E. (1993) Effect of consumption of lactic cultures on human health. Adv. Food Nutr. Res. 37, 67-130.

25. SAS. (2000) SAS/STAT user's guide. Version 8, SAS Institute Inc., Cary, N. C., USA

26. Sato, K., Saito, H., Tomioka, H., and Yokokura, T. (1988) Enhancement of host resistance against Listeria Infection by Lactobacillus casei: efficacy of cell wall preparation of Lactobacillus casei. Microbiol. Immunol. 32, 1189-1200.

27. Schleifer, K. H., and Kandler, O. (1972) Peptidoglycan types of bacterial cell walls and their taxonomic implications. Bacteriol. Rev. 36, 407-477.

28. Sekine, K., Kasashima, T., and Hashimoto, Y. (1994) Comparison of the TNF- $\alpha$ level induced by human-derived Bifidobacterium longum and rat-derived Bifidobacterium animalis in mouse peritoneal cells. Bifidobact. Microfl. 13, 79-89.

29. Sekine, K., Ohta, J., Onishi, M., Tatsuki, T., Shimokawa, Y., Toida, T., Kawashima, T. and Hashimoto, Y. (1995) Analysis of antitumor properties of effector cells stimulated with a cell wall preparation of Bifidobacterium infantis. Biol. Pharm. Bull. 18, 148-153.

30. Takahashi, T., Oka, T., Iwana, H., Kuwata, T., and Yamamoto, Y. (1993) Immune response of mice to orally administered lactic acid bacteria. Biosci. Biotech. Biochem. 57, 1557-1560.

31. Takahashi, T., Nakagawa, E., and Nara, T. (1998) Effects of orally ingested Bifidobacterium longum on the mucosal Immunoglobulin A response of mice to dietary antigens. Biosci. Biotech. Biochem. 62, 10-15.

32. Tejada-Simon, M. V., and Pestka, J. J. (1999) Proinflammatory cytokine and nitric oxide induction in murine macrophages by cell wall and cytoplasmic extracts of lactic acid bacteria. J. Food Prot. 62, 1435-1444.

33. Trinchieri, G. (1994) Interleukin-12: a cytokine produced by antigen-presenting cells with immunoregulatory functions in the generation of T-helper cells type 1 and cytotoxic lymphocytes. Blood 84, 4008-4027.

34. Uemura, J., Kitazawa, H., Kawai, Y., Itoh, T., Oda, M., and Saito, T. (2003) Functional alteration of murine macrophages stimulated with extracellular polysaccharides from Lactobacillus delbrueckii ssp. bulgaricus OLL1073R-1. Food Microbiol. 20, 267-273.

35. Vinderola, G., Perdigon, G., Duarte, J., Farnworth, E., and Mater, C. (2006) Effects of the oral administration of the products derived from milk fermentation by kefir microflora on immune stimulation. J. Dairy Res.7, 1-8.

$\overline{\text { (Received 2010.7.8/Revised 2010.9.13/Accepted 2010.9.21) }}$ 